\title{
Experimental Study on the Effect of Heel Plate Length on the Structural Integrity of Cold-formed Steel Roof Trusses
}

\author{
Je Chenn Gan ${ }^{1}$, Jee Hock Lim $^{1 *}$, Siong Kang Lim ${ }^{1}$, and Horng Sheng Lin ${ }^{1}$ \\ ${ }^{1}$ Lee Kong Chian Faculty of Engineering and Science, Universiti Tunku Abdul Rahman, Jalan Sungai \\ Long, Bandar Sungai Long, Cheras, 43000 Kajang, Selangor, Malaysia
}

\begin{abstract}
Applications of Cold-Formed Steel (CFS) are widely used in buildings, machinery and etc. Many researchers began the research of CFS as a roof truss system. It is required to increase the knowledge of the configurations of CFS roof trusses due to the uncertainty of the structural failures regarding the materials and rigidity of joints. The objective of this research is to investigate the effect of heel plate length to the ultimate load capacity of CFS roof truss system. Three different lengths of heel plate specimens were fabricated and subjected to concentrated loads until failure. The highest ultimate capacity for the experiment was $30 \mathrm{kN}$. The results showed that the increment of the length of the heel plate had slightly increased the ultimate capacity and strain. The increment of the length of the heel plate had increased the deflection of the bottom chords but decreased the deflection of the top chords. Local buckling of top chords adjacent to the heel plate was the primary failure mode for all the heel plate specimens.
\end{abstract}

\section{Introduction}

Cold-formed steel (CFS) is composed of steel plate, sheet, and strip material. It is widely used for construction buildings, machinery, vehicles, and much more. CFS is frequently used as a secondary framing material [1]. Although, with the current development of CFS, it can be used as primary steel members because of its advantages [2]. The advantage for CFS such as high strength and stiffness, lightweight that can be transported easily and many more [1]. CFS had been introduced in Malaysia in recent years. CFS had been increased in the usage of CFS in new construction from housing areas to commercial buildings in Malaysia based on its advantages such as cost saving, recyclable material, and fast installation.

CFS compression member is critical to the limit states, such as yielding and buckling. All these limit states are relying on the cross-section geometry, length, and thickness [1]. Compression usually occurs at the chord members of trusses especially top chords and diagonal members in end panels of trusses. CFS compression members can indicate into three modes of instability or failure mode: local buckling, distortional buckling and flexural or flexural-torsional buckling $[3,4]$. CFS tension member depends on the yielding of the net

\footnotetext{
* Corresponding author: limjh@utar.edu.my
} 
cross section which excludes the region of member connection [5]. However, CFS tension members can easily affect a connection failure under tension. There is a limitation on deformation that a tension member can be accomplished, due to the limiting strength of tension member.

Elkersh [6] stated that the spacing between bolts did not change much on the ultimate capacity. However, the capacity did increase with the increase of gusset plate thickness. Craveiro, Rodrigues, and Laim [4] found out that the column with close built-up cross section had higher buckling load than other types of cross section of the columns. The authors did use a strain gauge to determine the condition and behaviour of the columns. Dawe and Wood [7] identified that the main failure modes for small-scale CFS roof trusses without intermediate members were local buckling of the top chord, followed by distortion of the heel plate. The authors proposed that adding edge stiffeners at the heel plate could reduce the distortion of the heel plate. Wood and Dawe [8] also determined that the major failure modes for full-scale CFS roof trusses were local buckling of the top chords, followed by crippling of the heel plate with the failure of the screws.

The purpose of this research was to eliminate the intermediate member within the normal conventional truss and substituted it with heel plate as a support near to the eaves. Besides that, ridge plates and horizontal members are installed at the peak to connect both sides of the top chords. It will create an additional living area within the truss system with this replacement. Further study in the detail of CFS roof truss was required. This was because of the details of CFS roof truss that can affect its performance was undecided, where different lengths can have different capacities, stresses, and strains. Therefore, the objective of this research is to investigate the effect of heel plate length to the ultimate load capacity of CFS roof truss system.

\section{Material and methods}

In this research, three specimens were fabricated with different lengths of heel plates. CFS C-channel section such as top chord, a bottom chord, horizontal member and purlin were assembled into a 4:12 roof pitch. The grade for CFS C-channel section used was G550. Whereas, the grade for other members were A36. Table 1 shows the dimensions for all the C-channel section.

Table 1. Dimensions of chord members.

\begin{tabular}{|c|c|c|c|}
\hline Web, $\mathrm{d}(\mathrm{mm})$ & Flange, $\mathrm{b}(\mathrm{mm})$ & Lip, $\mathrm{c}(\mathrm{mm})$ & Thickness, $\mathrm{t}(\mathrm{mm})$ \\
\hline 97 & 47 & 11 & 1 \\
\hline
\end{tabular}

All the members were supported by using a heel plate, additional plate, and ridge plate as shown in Fig. 1, Fig. 2 and Fig. 3 respectively. All the members were connected by M5 hexagonal head bolt and nut. The lengths of the heel plates used consisted of $150 \mathrm{~mm}, 200$ $\mathrm{mm}$ and $250 \mathrm{~mm}$. Fig. 4 shows the dimensions of the heel plate truss specimen. Fig. 5 and Fig. 6 show the configurations of a typical test setup for the heel plate truss specimen and conventional roof truss with intermediate members respectively. The conventional roof truss was fabricated to compare the ultimate capacity with the heel plate truss specimen. 


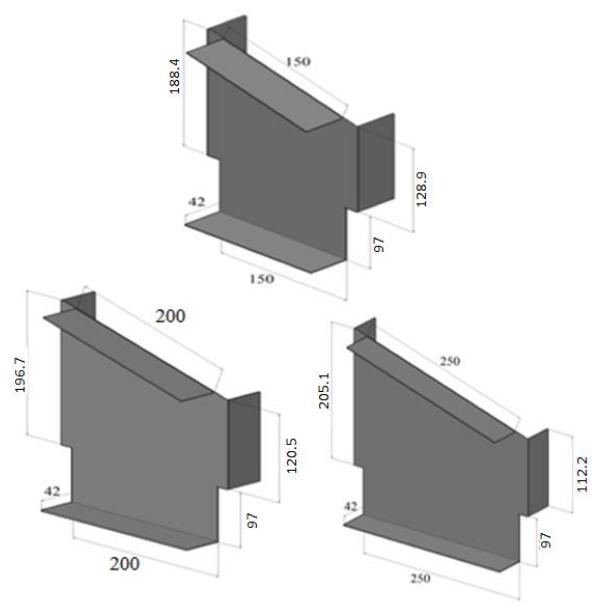

Fig. 1. Dimensions and configurations of heel plates.

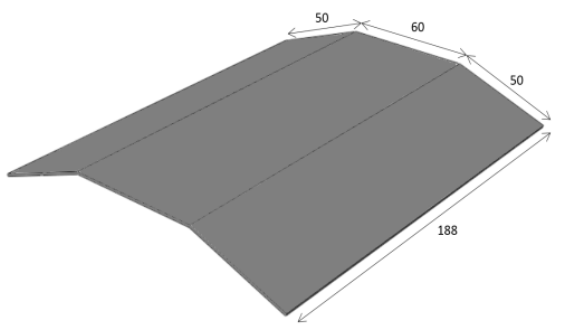

Fig. 2. Additional plate.

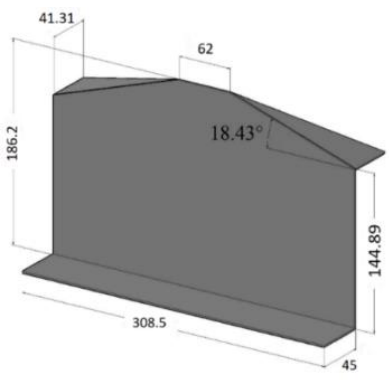

Fig. 3. Ridge plate.

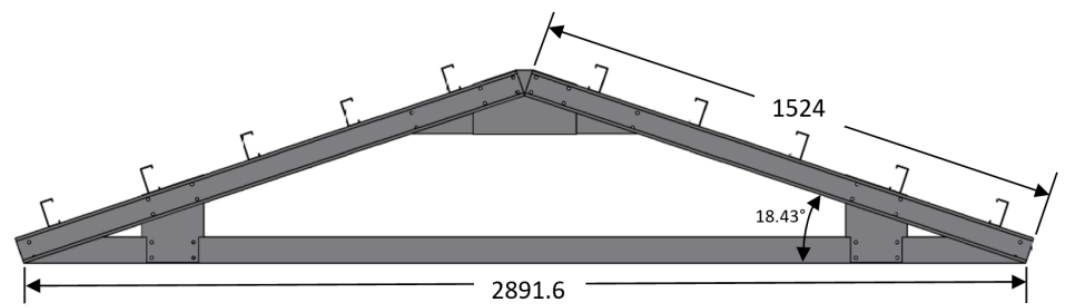

Fig. 4. Dimensions for heel plate CFS truss specimen.

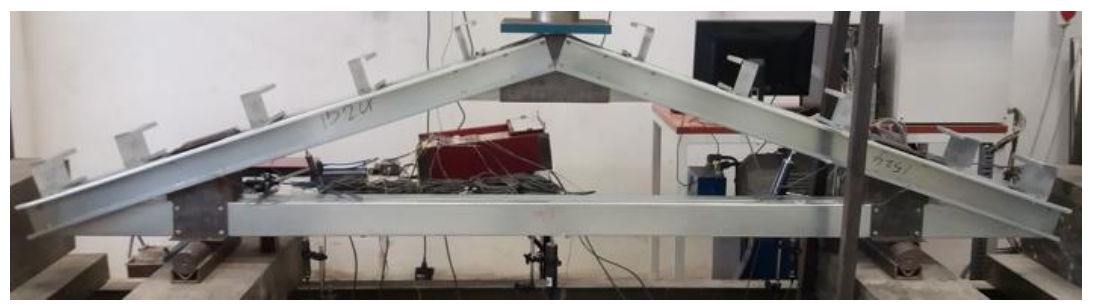

Fig. 5. Typical test setup for the heel plate CFS truss specimen. 


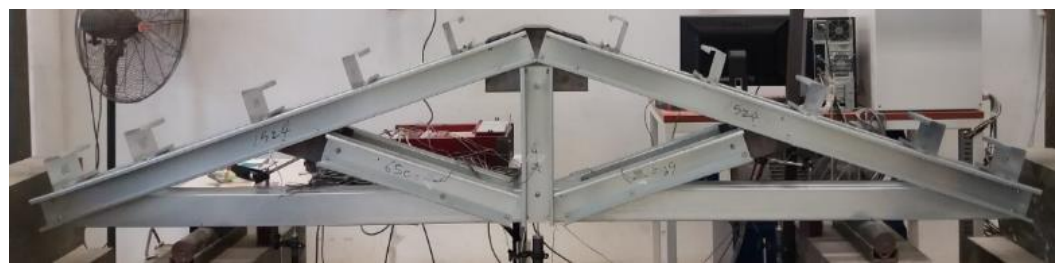

Fig. 6. Conventional CFS roof truss specimen.

All the CFS members were cut into tensile test specimens to determine the material properties with a loading rate of $2 \mathrm{~mm} / \mathrm{min}$ by using Model 5582 Instron universal testing machine according to ASTM A370 [9]. Table 2 shows the material properties for all the CFS members. All the results from Table 2 were based on average of triplicate.

Table 2. Material Properties for all the members.

\begin{tabular}{|c|c|c|c|c|c|}
\hline Member & $\begin{array}{c}\text { Thickness } \\
(\mathrm{mm})\end{array}$ & $\begin{array}{c}\text { Young } \\
\text { Modulus, E } \\
(\mathrm{GPa})\end{array}$ & $\begin{array}{c}\text { Yield } \\
\text { Strength, fy } \\
(\mathrm{MPa})\end{array}$ & $\begin{array}{c}\text { Ultimate } \\
\text { Strength, } \mathrm{fu}_{\mathrm{u}} \\
(\mathrm{MPa})\end{array}$ & $\begin{array}{c}\text { Strain } \\
\text { Elongation } \\
(\%)\end{array}$ \\
\hline CFS member & 1.0 & 191 & 623.65 & 640.76 & 6.04 \\
\hline Additional plate & 1.0 & 109 & 200.81 & 316.10 & 22.26 \\
\hline Ridge plate & 1.5 & 176 & 370.42 & 525.40 & 13.11 \\
\hline Heel plate & 3.0 & 163 & 326.78 & 474.68 & 18.70 \\
\hline
\end{tabular}

The ultimate capacity and failure mode for all the specimens were determined by using $300 \mathrm{kN}$ structural reaction frame subjected to an area load at the ridge [7]. Load capacity, deflection, strain and failure mode of the specimens were analyzed and the load was plotted against deflection and strain.

The positions of LVDTs were referred to Mohammad, Tahir, Tan \& Shek [10] as shown in Fig.7. LVDTs 1 and 5 were placed at the midspan of the top chord to determine the vertical deflection of top chords. Besides, LVDT 3 was positioned at the middle of the bottom chord to identify the maximum vertical deflection of the bottom chord. Whereas, LVDTs 2 and 4 were installed with a distance of $722.9 \mathrm{~mm}$ away from LVDT 3 to verify the load balancing.

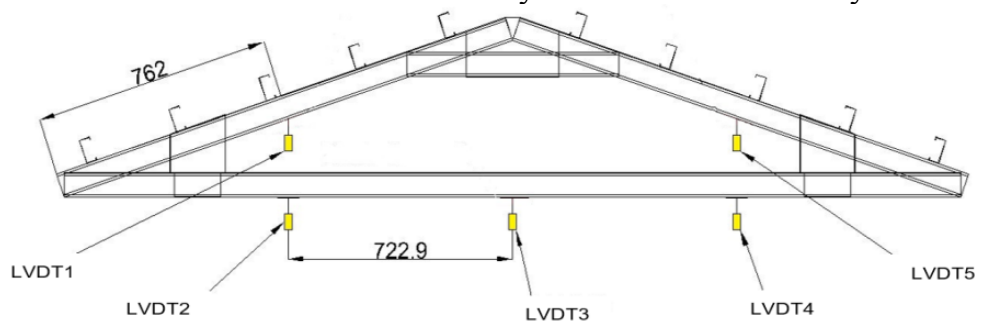

Fig. 7. Positions of LVDTs.

Strain gauges were used to measure the strain. Fig. 8 shows the location of the strain gauges. All of the strain gauges were placed in the midspan of the chord member.

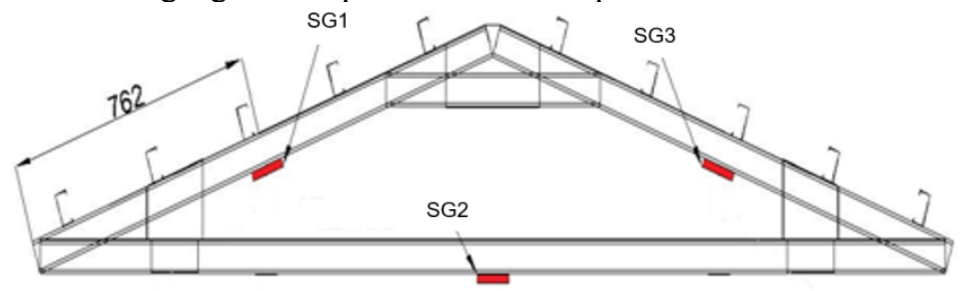

Fig. 8. Positions of the strain gauge. 


\section{Experimental results}

Table 3 shows the ultimate load capacity, deflection, and strain data for all the specimens.

Table 3. Ultimate load, deflection and strain data for all specimens

\begin{tabular}{|c|c|c|c|c|c|c|c|c|c|}
\hline \multirow{3}{*}{ Specimen } & \multirow{3}{*}{$\begin{array}{l}\text { Ultimate } \\
\text { Load } \\
(\mathrm{kN})\end{array}$} & \multicolumn{5}{|c|}{ Ultimate Deflection (mm) } & \multirow{2}{*}{\multicolumn{3}{|c|}{$\begin{array}{c}\text { Ultimate Strain }(\mu \varepsilon) \\
\text { SG }\end{array}$}} \\
\hline & & \multicolumn{5}{|c|}{ LVDT } & & & \\
\hline & & 1 & 2 & 3 & 4 & 5 & 1 & 2 & 3 \\
\hline Conve & 21.0 & -7.472 & -1.316 & -11.155 & -2.008 & -7.710 & 67 & 1425 & 44 \\
\hline T3I & 28.0 & .165 & -1 . & -0.288 & -0.764 & -4. & -683 & 101 & -638 \\
\hline T3 & 28.0 & -3.255 & -2.334 & -1.764 & -2.012 & -3.0 & -716 & -34 & -645 \\
\hline T3L250 & 30.0 & -3.695 & -2.044 & -1.582 & -1.888 & -3.445 & -1140 & 52 & -1099 \\
\hline
\end{tabular}

${ }^{a} \mathrm{~T} 3$ indicates as $3 \mathrm{~mm}$ thickness of the heel plate, L150 indicates as $150 \mathrm{~mm}$ length of the heel plate.

Based on Table 3, the ultimate capacity for heel plate truss specimens was in between from 28 to $30 \mathrm{kN}$. Buckling waves were formed at the top chord webs adjacent to the heel plate when the load applied around 18 to $20 \mathrm{kN}$. The failure mode for all the heel plate truss specimens was local buckling of top chords adjacent to the heel plates at all of the four top chords as shown in Fig. 9. Harper, LaBoube, and $\mathrm{Yu}$ [5] stated that removing the intermediate member of the truss will occur the failure of local buckling of top chords. As for conventional roof truss, the failure mode was local buckling of bottom chords at the support and distortional buckling of top chords at the ridge as shown in Figs. 10(a) and 10(b).

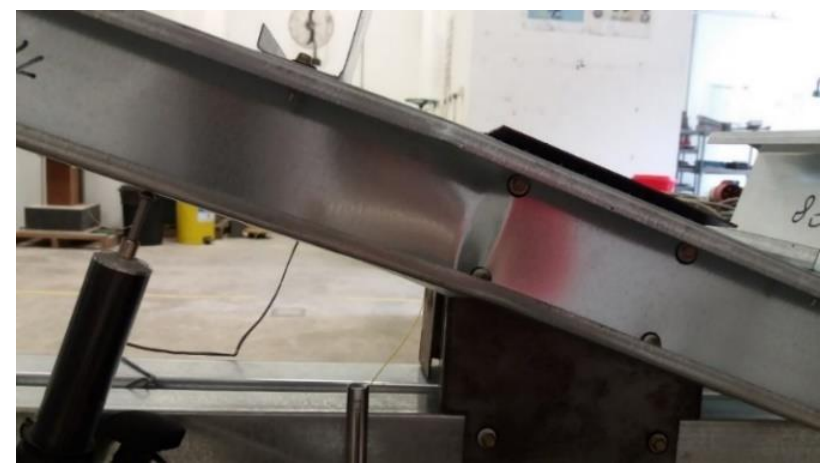

Fig. 9. Local buckling of top chord for heel plate truss specimen.

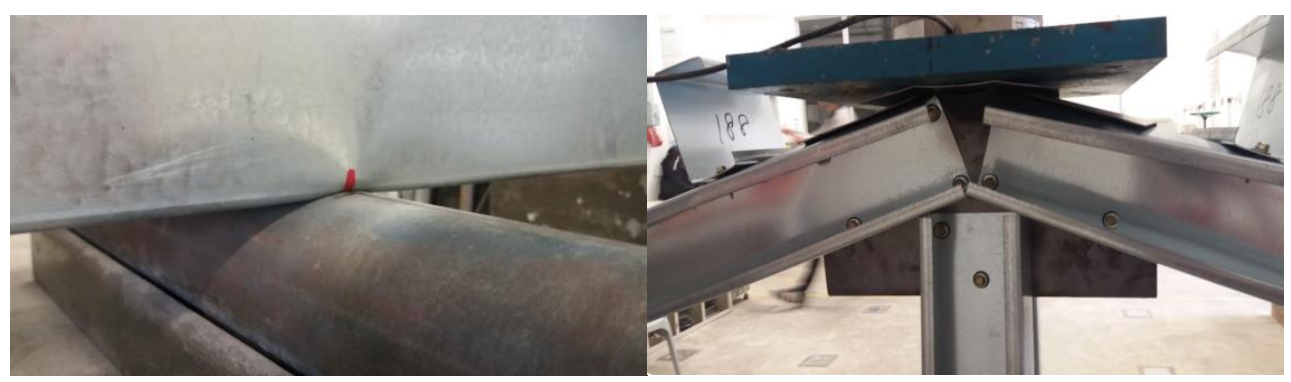

Fig. 10(a). Local buckling of bottom chord for conventional truss specimen.

Fig. 10(b). Distortional buckling of top chord for conventional truss specimen.

All the data were plotted with load against deflection and strain as shown in Fig. 11 to 16. The data from Table 3 showed that both sides of the top chords were in negative deflection, which was sagging deflection. LVDT3 for heel plate truss specimens were in hogging deflection. Whereas, both LVDTs 2 and 4 were in sagging deflection for heel plate 
truss specimens. LVDT3 for heel plate truss specimens were hogging deflection even though it was negative deflection. These were due to both LVDTs 2 and 4 were higher negative deflection compare to LVDT3. On the other hand, the bottom chords for conventional truss were in sagging deflection. Fig. 17 to 19 show the illustration of the top chords and bottom chords deflections for heel plate truss specimen. Figs. 20, 21 and 22 show the load against deflection, load against strain and the phenomena of the top chords and bottom chords deflections for conventional truss specimen respectively. According to the strain data from Table 3, all the top chords for the heel plate specimens had a negative strain, which was in compression. Whereas, all the bottom chords for the heel plate specimens had a positive strain, which was in tension except for T3L200 specimen. While all the chord members for conventional roof truss were in positive strain as shown in Table 3.

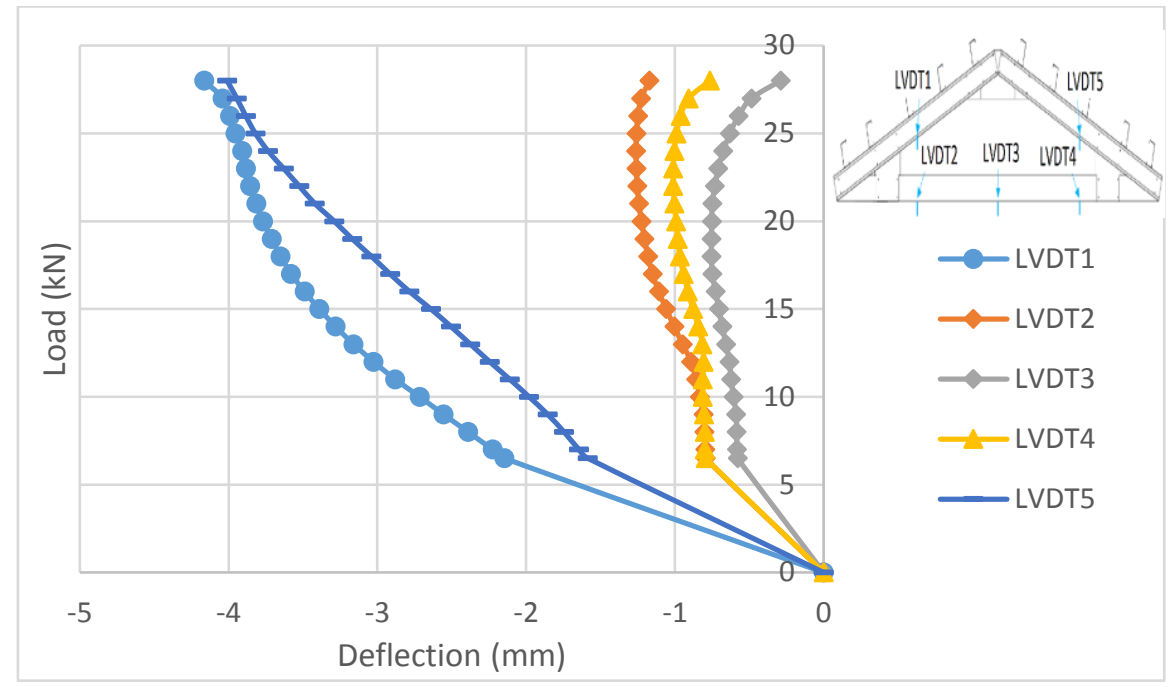

Fig. 11. Load versus deflection for T3L150 specimen.

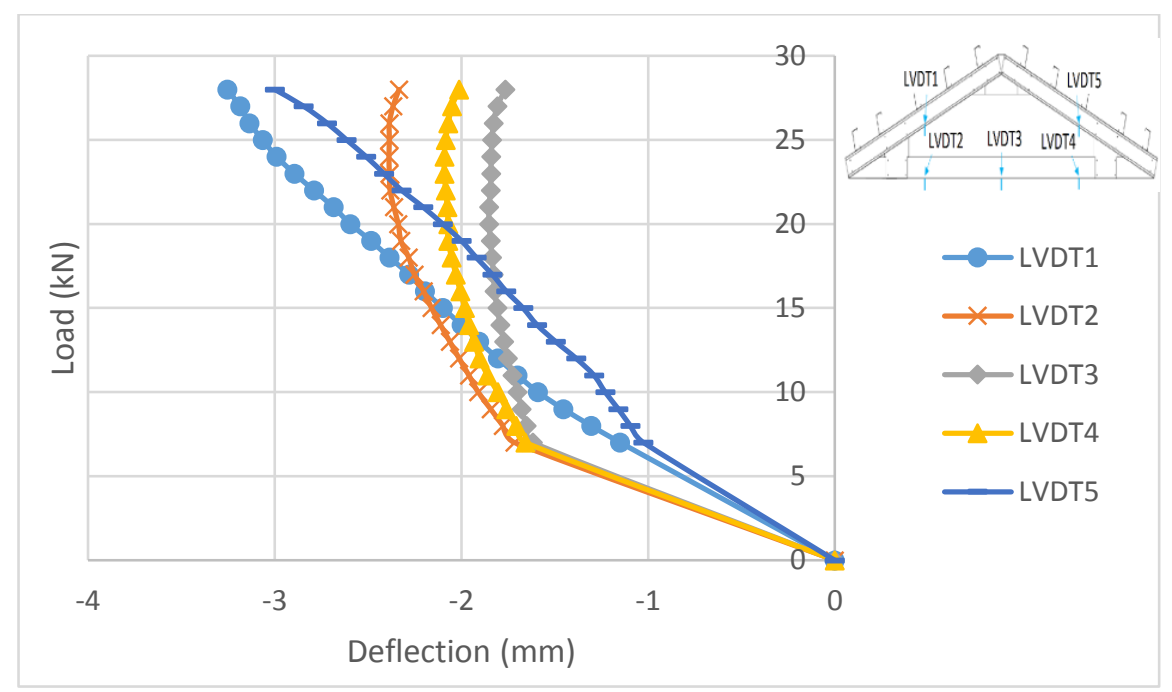

Fig. 12. Load versus deflection for T3L200 specimen. 


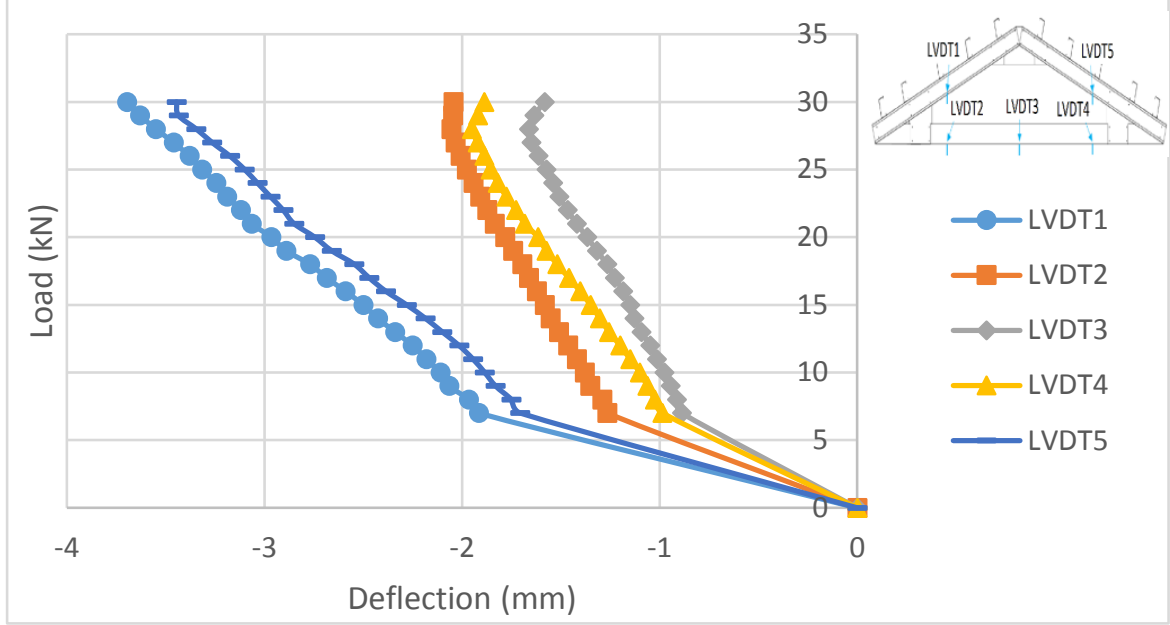

Fig. 13. Load versus deflection for T3L250 specimen.

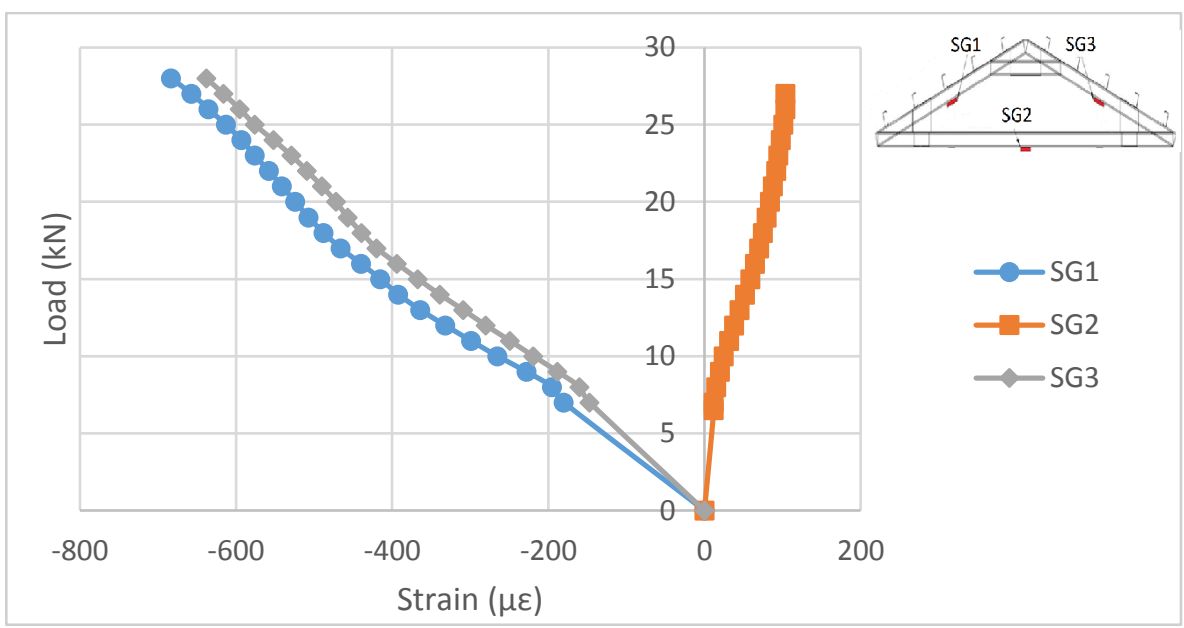

Fig. 14. Load versus strain for T3L150 specimen.

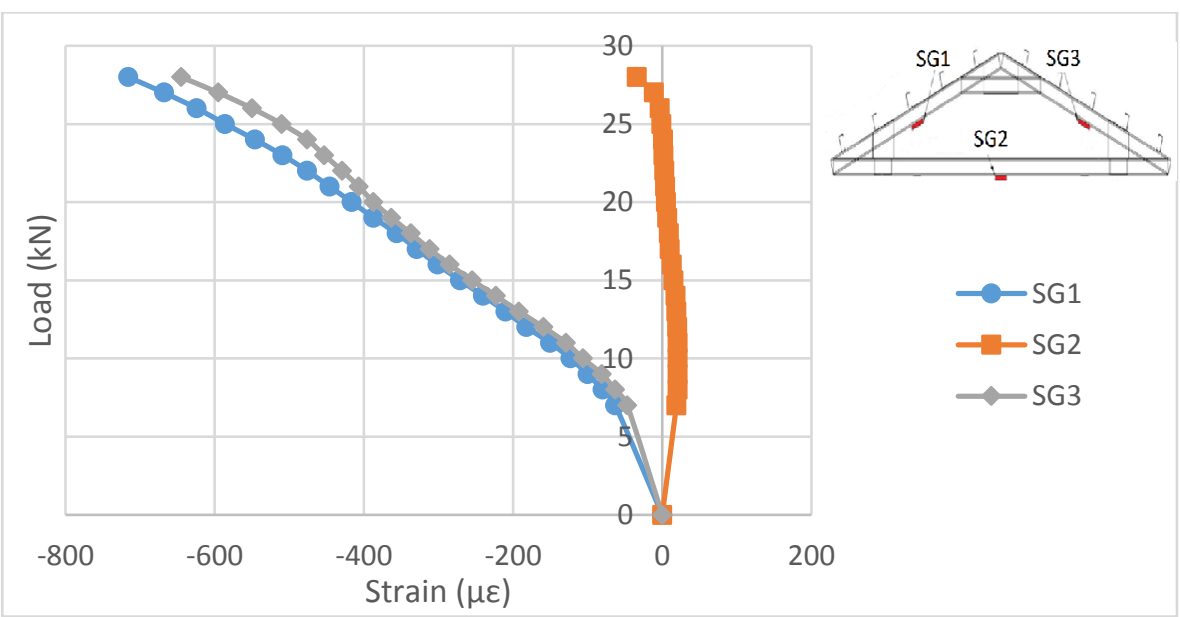

Fig. 15. Load versus strain for T3L200 specimen. 


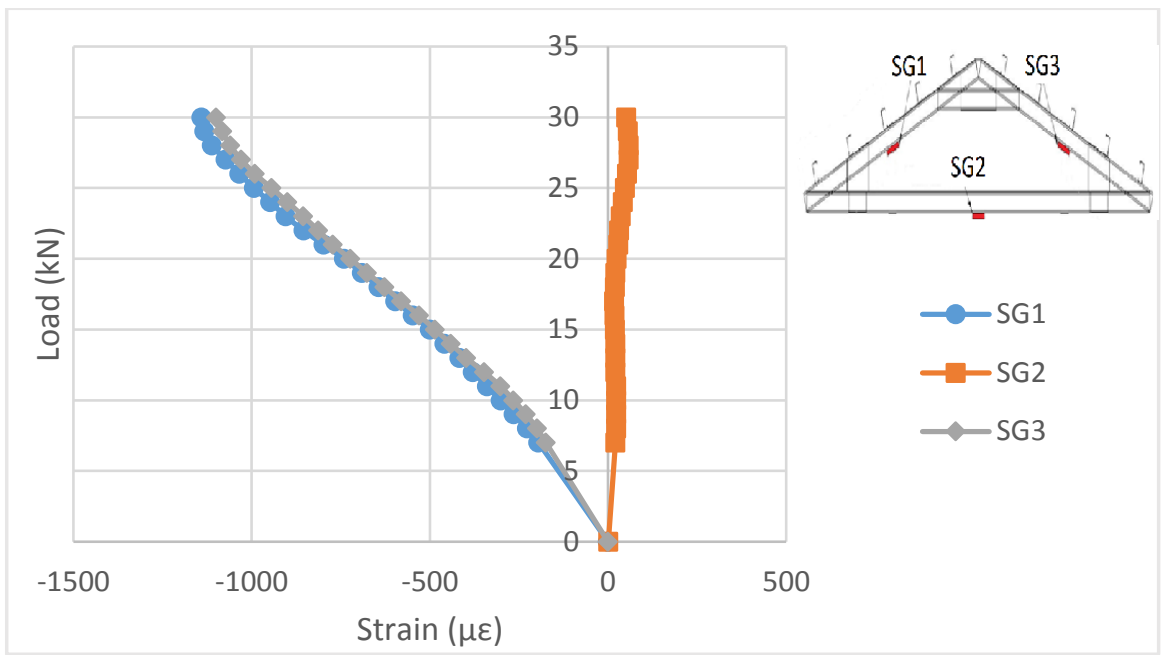

Fig. 16. Load versus strain for T3L250 specimen.

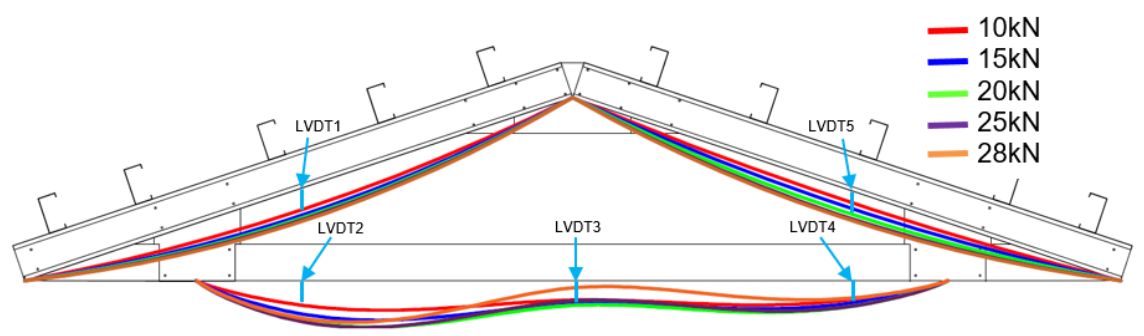

Fig. 17. Deflection for T3L150 specimen.

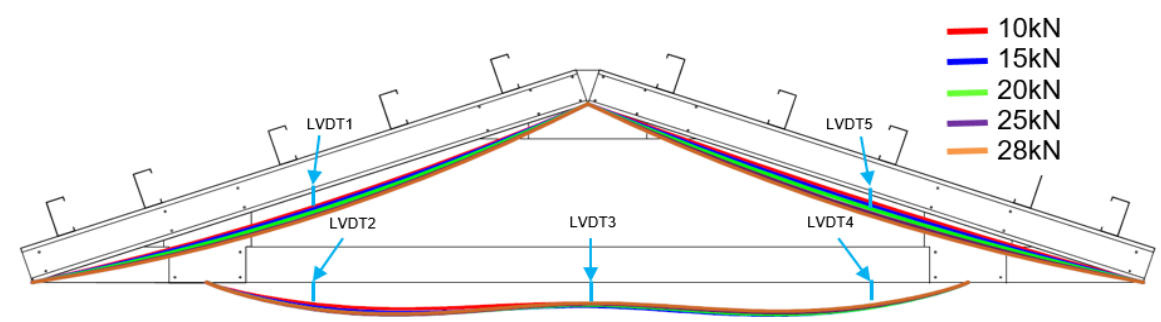

Fig. 18. Deflection for T3L200 specimen.

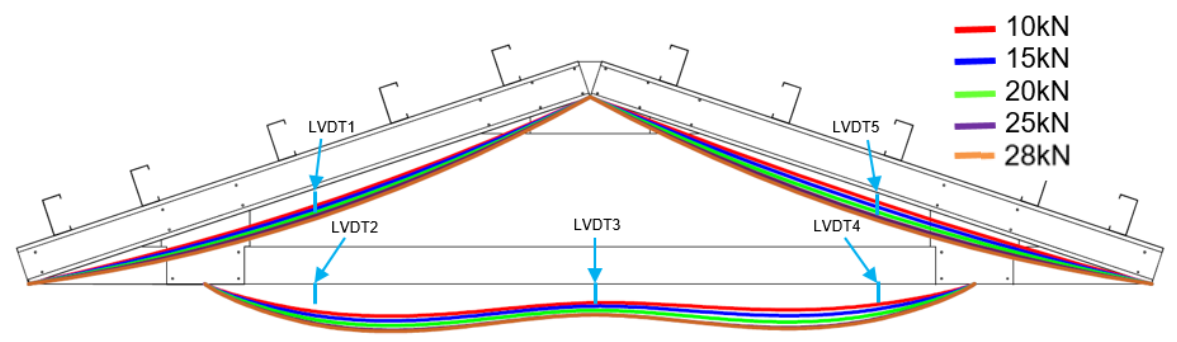

Fig. 19. Deflection for T3L250 specimen. 


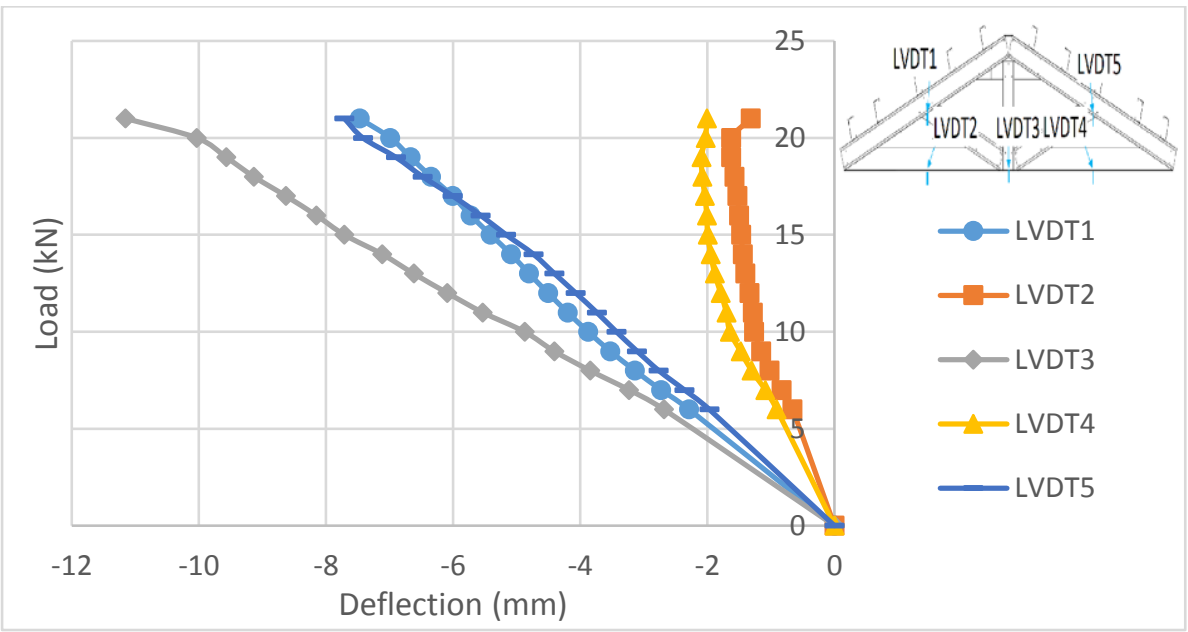

Fig. 20. Load versus deflection for conventional roof truss specimen.

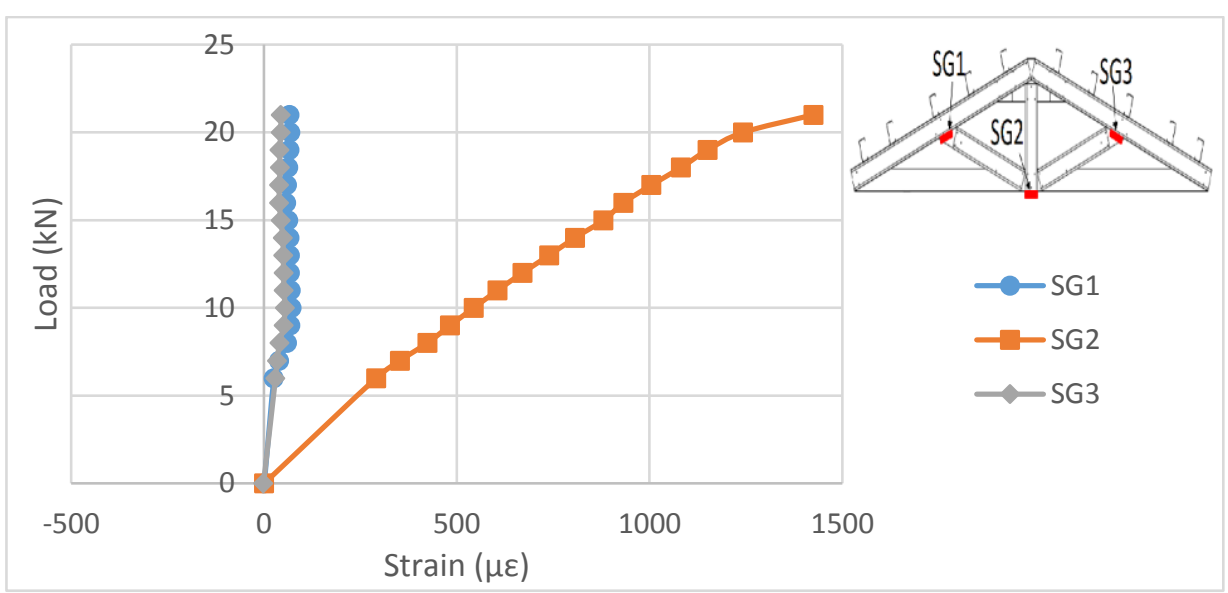

Fig. 21. Load versus strain for conventional roof truss specimen.

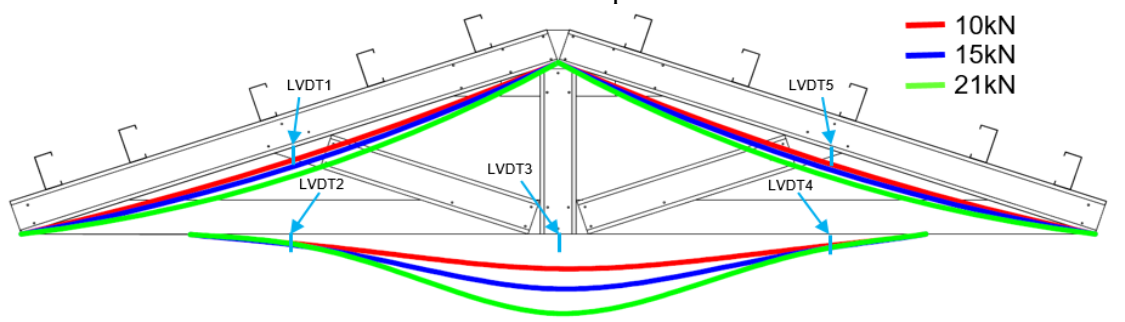

Fig. 22. Deflection for conventional truss specimen.

Generally, the ultimate load capacity increased as the length of the heel plate increased from $150 \mathrm{~mm}$ to $250 \mathrm{~mm}$. As for maximum deflection, the top chords for T3L150 specimen had the highest deflection followed by T3L250 and T3L200 specimens. These might be due to the effective length of the top chords for T3L150 specimen was longer than other specimens. Whereas, the bottom chords for T3L150 specimen had the lowest deflection followed by T3L250 and T3L200 specimens. These might due to the top chords for T3L150 specimen had absorbed almost all the energy and transferred the lesser load to the bottom chord. As the heel plate goes longer, the heel plates went closer towards the applied load, 
which resulting the load from the top chords transferred faster to the bottom chords than shorter heel plate specimen. However, all the data for T3L250 specimen were in the middle for both top and bottom chords. All the chord members for the conventional roof truss specimen had higher midspan deflection compared to all of the heel plate truss specimens. However, the ultimate load for the conventional truss specimen was lower than that of the heel plate truss specimens.

The ultimate strain for the top chords increased simultaneously with the length of the heel plate. These were due to the edge of the heel plate became closer to the position of strain gauge as the length of the heel plate increases, where the local buckling failure happened at the edge of the heel plate. Besides that, the strain of bottom chords for T3L150 specimen had the highest strain followed by T3L250 and T3L200 specimens. These might due to the deflection of the bottom chords, where the difference between LVDTs 2 and 4 with LVDT3 became higher along the order, a higher difference of the deflection affect the strain changed from tension to compression. However, the ultimate strain for bottom chords of the conventional truss was a high positive strain, because the middle of the intermediate member carried the load directly from the ridge to the bottom chords of the truss. Both side of the top chords for conventional truss was in a tension state. These might due to both sides of the intermediate members pulled down the top chords as the bottom chords went downward with the increment of the load capacity.

\section{Conclusion}

The experimental results were analyzed and discussed on three small-scale CFS roof truss specimens were fabricated with different lengths of the heel plate. The major failure mode for all of the heel plate specimens was local buckling of top chords adjacent to the heel plate. Whereas, the failure mode for conventional roof truss was distortional buckling of top chords at the ridge and local buckling of bottom chords at the support. The ultimate load capacity, ultimate deflection for bottom chords and ultimate strain for top chords slightly increased with the increment of the length of the heel plate. Whereas, the ultimate deflection for the top chord slightly decreased when the length of the heel plate increased. All the deflection mode for the heel plate truss specimens were sagging deflection at top chords and sagging hogging sagging deflection at bottom chords. As for conventional truss specimen, all of the chord members were in sagging deflection.

\section{References}

1. W. W. Yu and R. A. LaBoube, Cold-Formed Steel Design Fourth Edition (Missouri: John Wiley \& Sons, Inc., 2010)

2. J. Ye, I. Hajirasouliha, J. Becque and K. Pilakoutas, Thin Wall Struct. 101,1-13 (2015)

3. J. Rondal, J. Constr. Steel Res., 55, 155-158 (2000)

4. H. D. Craveiro, J. P. C. Rodrigues, and L. Laim, Thin Wall Struct., 106, 358-375 (2016)

5. M. M. Harper, R. A. LaBoube and W. W. Yu, CCFSS (1995)

6. I. Elkersh, ASEJ, 1, 11-20 (2010)

7. J. L. Dawe and J. V. Wood, J. Struct. Eng., 132(4), 608-615 (2006)

8. J. V. Wood and J. L. Dawe, J. Struct. Eng., 132(4), 616-623 (2006)

9. American Society of Testing and Materials, Standard test methods and definitions for mechanical testing of steel products Standard A370 (West Conshohocken, PA, 2000)

10. S. Mohammad, M. Md Tahir, C. S. Tan, and P. N. Shek, Appl. Mech. Mater., 166-169, 1304-130 (2012) 